\title{
Europe at sixes and sevens: a review
}

\author{
Emile Benoit, Europe at Sixes and Sevens
}

\section{GEORGE KISH}

Department of Geography, The University of Michigan

Professor Benoit (1) calls the program of European integration "the first significant Western innovation in statecraft since the nineteenth-century unification of Germany and Italy." His book manages that rare feat, to present the pertinent facts about a major economic-political development of our time in clear, concise, and well-written prose while combining it with a challenging discussion of the economic principles involved and with a "vade-mecum" for United States investments in Europe under the aegis of European integration.

The European Economic Community was born at a meeting of the foreign ministers of Italy, France, West Germany, Belgium, the Netherlands, and Luxemburg, held at Messina, Italy in 1955 . It was preceded by the organization of the European Coal and Steel Community, consisting of these six nations, and subsequent to the Messina organization session, a European Atomic Energy Agency was added to it. A good measure of the importance of EEC is its steel output, that puts it second in the world, behind the United States but slightly ahead of the Soviet Union. It represents a population bloc of 168 million people, with a GNP of 165 billion dollars (1959 figures). Furthermore, the six nations comprising the EEC have shown, since 1953, a growth rate that puts them in the van of world economic development.

In part as a countermeasure to the challenge presented by the EEC, seven European nations, led by Great Britain, and including, besides, Britain, Sweden, Norway, Denmark, Austria, Switzerland, and Portugal formed the European Free Trade Association in 1959. The combined population of the EFTA nations is 89 million, their GNP, in 1959 , amounted to 102 billions of dollars, but their growth rate since 1953 was decidedly lower than that of the members of the EEC. In August, 1961, Great Britain decided to apply for membership in the EEC, foreshadowing similar steps by other members of the group.

The possible, indeed probable economic integration of at least ten of the nations now comprising the two rival groupings of EEC and EFTA (membership of the neutral countries, Austria and Switzerland, may be delayed for political reasons, while Portugal considers itself somewhat marginal in relation to the other participants) may create within the foreseeable future an economic bloc of the same order of magnitude as the United States and the Soviet Union. Undoubtedly this is the most exciting development in world affairs since the rise 
of the Soviet Union to its present place as a major industrial power.

Professor Benoit introduces his discussion of the problems involved in European economic integration with a brief, exceedingly clear, and useful description of the history, organization, and probable development of the European Economic Community. The burden of his book, however, is in presenting the role of EEC as a pioneer organization in developing more than a mere customs union, by formulating over-all economic policy, and in analyzing the impact such an organization may have on the United States and on the Western world. His analysis of American competitiveness in European and other markets is strikingly original, thoroughly documented, and fully illustrative of the challenge United States producers face in the evolving world economy. Just as dollar gap changed into dollar glut between 1945 and 1960, so Europe, having made a spectacular recovery following World War II, has by now far exceeded its pre-war economic levels and gone on to the conquest of new markets both in the United States and in the world at large.

Benoit's analysis is not restricted to theories on business structure alone. Chapter V of his book, entitled "Business Opportunities in an Integrated Europe," is a handy guide to potential investors, providing an accurate thumbnail sketch of the economy of each of the European nations involved in integration. His is an approach born out of profound knowledge of these countries, tempered by a practical viewpoint that realizes American business impulsiveness and European business conservatism, and suc- cessfully anticipates many of the problems arising from the clash of these two. At a time when American business is becoming more and more aware of investment opportunities abroad and when both our foreign investment portfolio and the proportion of profits derived from foreign investments show steadily rising levels, such a presentation is of the greatest value to the business community as well as to the academic investigator.

European economic integration through the efforts of the EEC is what may be called a "functional" approach to eventual political integration. The author's proposals for bringing nations in particularly vulnerable positions, e.g., Finland and Austria, into the Community as "associate" members; for compensation to nations, such as members of the Commonwealth, for losses suffered as a result of measures taken by the Community; present a brilliant blending of solid economic theory and sound political sense born out of long experience.

Europe at Sixes and Sevens may well be described as the right book, published at the right time, about one of the key problems of our time. It is a major contribution to the scholarly literature of economic conflict, and a most valuable guide to civil servant, businessman, and interested layman to the problems and prospects of European integration.

\section{REFERENCE}

1. Benort, EMnLE. Europe at Sixes and Sevens: The Common Market, The Free Trade Association, and the United States. New York: Columbia University Press, 1961. 